Ambiente \& Água - An Interdisciplinary Journal of Applied Science
ISSN 1980-993X - doi:10.4136/1980-993X
www.ambi-agua.net
E-mail: ambi.agua@gmail.com

\title{
Post-treatment of landfill leachate using rice husk ash as adsorbent medium
}

\author{
ARTICLES doi:10.4136/ambi-agua.2350
}

Received: 27 Nov. 2018; Accepted: 29 Apr. 2019

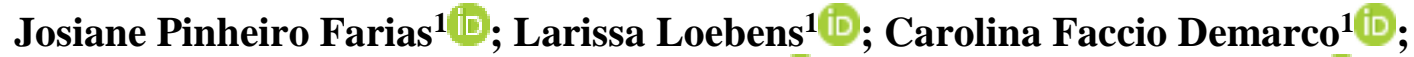 \\ Tito Roberto Sant'Anna Cadaval Junior ${ }^{2}{ }^{\mathbb{D}}$; Maurizio Silveira Quadro ${ }^{1}$; \\ Robson Andreazza ${ }^{*}$ (D)
${ }^{1}$ Universidade Federal de Pelotas (UFPEL), Pelotas, RS, Brasil
Centro de Engenharias (CEng). E-mail: jo.anetst@yahoo.com.br, laryloebens2012@gmail.com, carol_demarco@hotmail.com, mausq@hotmail.com,robsonandreazza@yahoo.com.br
${ }^{2}$ Universidade Federal do Rio Grande (FURG), Rio Grande, RS, Brasil
Escola de Química e Alimentos (EQA). E-mail: titoeq@ gmail.com
"Corresponding author

\begin{abstract}
Sanitary landfill is the most disposal method for urban solid waste. However, in the process of organic matter degradation, a dark-colored liquid with high potential for polluting is produced, necessitating an efficient treatment before its discharge into watercourses. Several technologies can be used in the treatment, such as biological and physico-chemical systems. The activated carbon produced from agricultural residues - rice husk ash (RHA), appears as an alternative treatment, mainly for color reduction in landfill leachate. This study determined the best operational condition for the slurry treatment using a fixed-bed column. The column was filled with activated RHA and support material (sand). The column heights studied were $5 \mathrm{~cm}$ (C1) and $20 \mathrm{~cm}$ (C2) of adsorbent. The column with $20 \mathrm{~cm}$ of RHA and sand intercalated with the coal layer showed better efficiency in removal of the chemical oxygen demand (COD), with COD removal efficiency of $88.91 \%$ and rupture time of $120 \mathrm{~min}$. The removal of apparent color was $87.40 \%$ with the rupture time of $40 \mathrm{~min}$ and true color removal of $86.64 \%$ with rupture time of $50 \mathrm{~min}$. Activated rice husk ash was shown to be promising for post-treatment of the leachate with substantial efficiency.
\end{abstract}

Keywords: agricultural waste reuse, basic activation, fixed-bed column.

\section{Pós tratamento de lixiviado de aterro sanitário utilizando cinza de casca de arroz como meio adsorvente}

\section{RESUMO}

O aterro sanitário é o método mais geral de disposição de resíduos sólidos urbanos. Porém, no processo de degradação da matéria orgânica é produzido um líquido de coloração escura de alto potencial poluente sendo necessário tratamento adequado antes de seu lançamento nos corpos de água. Diversas tecnologias podem ser utilizadas no tratamento, como sistemas biológicos e método físico-químico. O carvão ativado produzido a partir de resíduos agrícolas, cinza de casca de arroz (CCA), surge como alternativa para o tratamento, principalmente para a redução de cor em lixiviados de aterro. Este trabalho determinou a melhor condição 
operacional para o tratamento de chorume utilizando uma coluna de leito fixo. A coluna foi preenchida com CCA ativada e material suporte (areia). As alturas de coluna estudadas foram $5 \mathrm{~cm}(\mathrm{C} 1)$ e $20 \mathrm{~cm}$ (C2) de adsorvente. A coluna com $20 \mathrm{~cm}$ de CCA e areia intercalada com a camada de carvão apresentou melhor eficiência na remoção de carga orgânica (DQO), com eficiência de remoção de DQO de $88,91 \%$ e tempo ruptura de $120 \mathrm{~min}$. A remoção de cor aparente foi de $87,40 \%$ com tempo de ruptura de 40 min e a remoção a cor verdadeira de $86,64 \%$ com tempo de ruptura de $50 \mathrm{~min}$. A cinza de casca de arroz ativada mostrou-se promissora para pós tratamento de lixiviado com eficiência.

Palavras-chave: aproveitamento de resíduos agrícolas, ativação básica, coluna de leito fixo.

\section{INTRODUCTION}

Urbanization exploits natural resources and generates a large amount of Municipal Solid Waste (MSW). These wastes cause much environmental damage, and highlight the need for adequate treatment (Andrade and Ferreira, 2011). Among the most common techniques of treatment and final disposal of solid wastes are reduction, compaction, milling, animal feed, composting, anaerobic digestion, incineration, launching in sewage treatment systems and deposition in dumps and landfills. Among the techniques used, the landfill is an environmentally adequate disposal method commonly employed. However, leachate is formed from the percolation of rainwater through the the wastes, and it that carries pollutant compounds with high levels of ammoniacal nitrogen (NH3 and $\mathrm{N}$ ), biochemical oxygen demand (BOD5), oxygen demand (COD), color (humic substances), heavy metals and suspended solids (Mojiri et al., 2014).

Due to its characteristics, the release of leachate without proper treatment can lead to contamination of surface and groundwater. Slurry treatment is therefore essential. Many technologies can be used in the treatment, such as biological systems and physico-chemical methods. Among the technologies, activated carbon has been used to remove several pollutants from the effluents, and it presents high efficiency in the removal of non-biodegradable compounds from the leachate (Hosseini et al., 2015; Mojiri et al., 2014).

Some studies involving only the adsorption process combined with biological reactors showed good efficiency in the reduction of the recalcitrant organic matter, color and other contaminants present in the leachate (Anju and Kani, 2017; Kasman and Ibrahim, 2016; Mojiri et al., 2014). However, there are few studies using rice husk ash resulting from the boiler combustion process of the rice-processing companies, as well as the use of low-cost adsorbents in the treatment of real effluents.

Anju and Kani (2017) studied the removal of turbidity, oxygen demand and suspended solids from a landfill leachate using activated rice husk ash as adsorbent; however, the authors used rice husk as a previously washed precursor for the removal of impurities to subsequent carbonization and ash activation.

In this context, this study evaluated the use of activated rice husk ash as adsorbent product in a dynamic system for the post-treatment process of leachate from the landfill of the city of Candiota/RS, which receives wastes from 19 municipalities in the Southern region.

\section{MATERIALS AND METHODS}

The study was carried out at the Laboratory of Analysis of Water and Effluents, located at the Center of Engineering (CEng) of the Federal University of Pelotas (UFPel).

\subsection{Leachate characterization}

The leachate used was sampled from the landfill of the South Half at latitude $-31,56873500$ and longitude -53, 73099600 in the municipality of Candiota of the State of Rio Grande do Sul 
(RS). The effluent was collected by the technician responsible for the sanitary landfill in the last anaerobic lagoon and stored in a 25-liter container and sent to the Laboratory.

The effluent used in this study was characterized according to the parameters of Chemical Demand of Oxygen, pH, Apparent and True Color at the input and output of the fixed-bed system with active carbon of rice husk ash, according to the methodology described by APHA et al. (2005).

\subsection{Activated carbon used}

The activated carbon used was from rice husk ash (RHA) from a rice-processing industry located at Pelotas/RS. The company uses the rice husk for generating thermal energy, conducting the firing in a grid-type reactor at a temperature of $800^{\circ} \mathrm{C}$.

The activation of RHA was performed with sodium hydroxide as activating agent. In this process, $600 \mathrm{~g}$ of the raw material was separated, to which was added $600 \mathrm{~g}$ of sodium hydroxide dissolved in 2 liters of distilled water with a ratio of 1:1 ( NaOH/ash). The mixture was maintained in contact for 24 hours, then it was washed with distilled water in order to achieve neutrality and to remove the reagents and impurities. Afterwards, the materials were dried in an oven at $110^{\circ} \mathrm{C}$ for 24 hours.

The concentration of the activating agent was established based on the study by Muniandy et al. (2014) with a difference in impregnation time. The methodology chosen for the ashwashing process was based on the work of Le Van and Luong Thi (2014), who also produced activated carbon from rice husk ash.

\subsection{Characterization of pulverized activated carbon}

The physical characterization was performed using the methodologies described by the Brazilian Technical Standards Association (MB 3414/1991, MB 3413/1991 and MB 3412/ 1991). The main characteristics of activated carbon ash used in the test were: humidity of 2.37 $\pm 0.2 \%$, apparent specific mass of $0.25 \pm 0.004 \mathrm{~g} . \mathrm{cm}^{-3}$, methylene blue of $10,05 \pm 0,70 \mathrm{mg} \cdot \mathrm{g}^{-1}$ and granulometry (\% passing mass) of $38.8 \pm 2.35 \%, 80.2 \pm 1.64 \%$ and $97.4 \pm 0.05 \%$ in sieves of $\mathrm{n}^{\circ} 100, \mathrm{n}^{\circ} 200$ and $\mathrm{n}^{\circ} 325$, respectively.

The morphological and elemental composition of the precursor surface (RHA) and activated carbon was mapped with the Scanning Electron Microscopy (SEM) system coupled to an EDS system. The analyses were carried out using a scanning electron microscope (JEOL JSM 6610, Japan). The samples were metalized with gold. A $15 \mathrm{kV}$ voltage acceleration was used and magnification ranges from 50 to 2500 times. The morphology and elemental composition was carried out at the Laboratory of Unitary Operations of the Chemical Engineering Course of the Federal University of Rio Grande (FURG). The EDS spectrum for raw rice husk and activated carbon are shown in Figures 1 and 2.

A

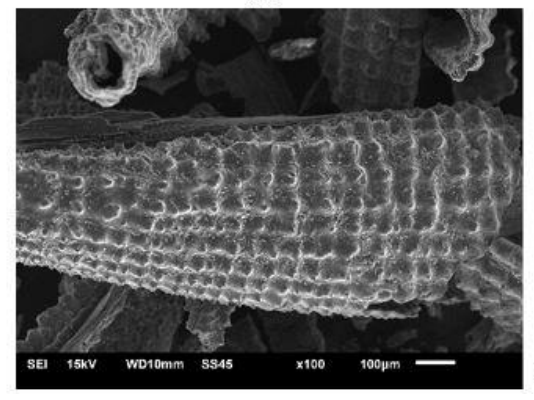

B

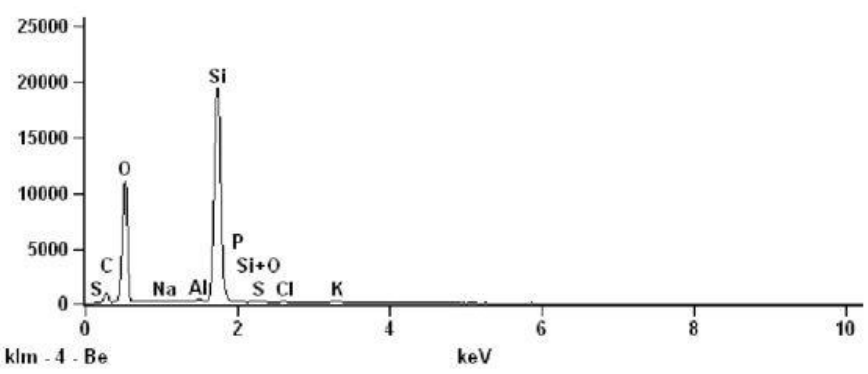

Figure 1. ESD spectrum for raw Rice Husk Ash (RHA). 

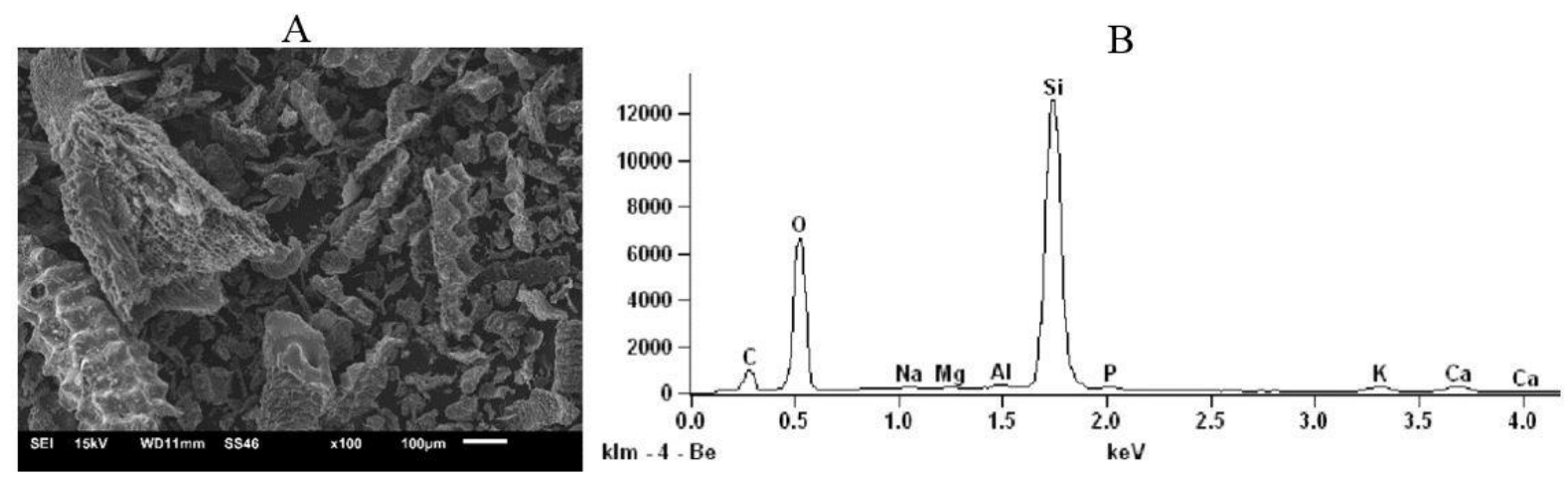

Figure 2. EDS spectrum for chemically activated carbon with $\mathrm{NaOH}$.

Figure 1A shows the formation of a material with a structure of interstices more evident, suggesting the appearance of the porous structure. From Figures $1 \mathrm{~B}$ and $2 \mathrm{~B}$, the majority of silicon and oxygen can be seen, still presenting in its composition sulfur, carbon, calcium, magnesium, sodium, aluminium, phosphorus, chlorine, silicon oxide and potassium.

\subsection{Adsorption Assays in Fixed-Bed Column}

For the down flow adsorption tests, a column of glass was adjusted with a length of $30 \mathrm{~cm}$, internal diameter of $5 \mathrm{~cm}$, and the flow was maintained by a prototype with a peristaltic pump developed at the laboratory.

Two tests were carried out in the column of activated carbon of rice husk ash called $\mathrm{C} 1$ and $\mathrm{C} 2$. The $\mathrm{C} 1$ test presented a bed height of $5 \mathrm{~cm}$ and $\mathrm{C} 2$ presented a bed height of $20 \mathrm{~cm}$, corresponding to adsorbent masses of 24 and 95 grams, respectively. The experiments were performed in triplicate for each treatment.

The system was placed the lower base of the column in wire screens, in order to retain particles which are eventually flow in the liquid and can obstruct or decrease the operating capacity of the system. A layer of sand was then placed over the screen, as a support layer for the adsorbent, whose particles were compacted with a little shaking. Subsequently, a layer of coal was introduced, which also was compacted. Finally, a layer of pebbles was added to the upper base to facilitate distribution of the flow through the adsorbent layer, thus minimizing the effects of forming preferred paths during its operation.

In the $20 \mathrm{~cm}$ bed height column, the sand was distributed in the base and in the core of the column, to act as a support and diffuser for liquid within the bed.

The beginning of the test occurred when the system was completely filled with the sample and the flow rate adjusted. Therefore, the first few minutes of effluent collection was discarded. Subsequently, samples were taken at intervals of 10, 20, 30, 40, 50, 60, 90, 120, 150, 180, 210 and 220 minutes, in order to evaluate the concentration at the output of the column. The analyzed parameters were COD and color. The effluent was repressed by a pump with a flow rate of $8 \mathrm{~mL} \cdot \mathrm{min}^{-1}$. All assays were performed at room temperature.

\subsection{Fixed-bed Column data analysis}

The adsorption capacity of the column was determined by the following Equation 1:

$q=\frac{C_{0} Q}{m_{s}} \int_{0}^{t}\left(1-\frac{c}{c o}\right) d t$

Being, $\mathrm{q}=$ the adsorption capacity of the adsorbent $\left(\mathrm{mg} \mathrm{g}^{-1}\right)$; Co = initial concentration of the fluid in the input $\left(\mathrm{mg} \mathrm{L}^{-1}\right) ; \mathrm{C}=$ concentration of the fluid at the output of the column $\left(\mathrm{mg} \mathrm{L}^{-1}\right)$; 
$\mathrm{Q}=$ volumetric flow rate of the solution $\left(\mathrm{L} \mathrm{min}^{-1}\right) ; \mathrm{t}=$ time $(\mathrm{min}) ; \mathrm{m}_{\mathrm{s}}=$ dry mass of the adsorbent (g).

Removal efficiency was calculated by the following Equation 2:

$\% R=\frac{\left(C_{o}-C\right)}{C_{0}} * 100$

Being, $\% \mathrm{R}=$ Removal percentage; $\mathrm{Co}=$ initial concentration of the fluid in the input $\left(\mathrm{mg} \mathrm{L}^{-1}\right) ; \mathrm{C}=$ concentration of the fluid at the output of the column $\left(\mathrm{mg} \mathrm{L}^{-1}\right)$.

The time of the Breakthrough was obtained by the curve inclination of the adsorbate concentration at the output of the bed, which consists of the ratio of $\mathrm{C} / \mathrm{C}_{0}$ against the time. The break point was considered from $\left(\mathrm{C} / \mathrm{C}_{0}\right) \geq 0.3$ for $\mathrm{C} 1$ and $\left(\mathrm{C} / \mathrm{C}_{0}\right) \geq 0.1$ for $\mathrm{C} 2$ and saturation point $\left(\mathrm{C} / \mathrm{C}_{\mathrm{o}}\right) \geq 0.8$ for $\mathrm{C} 1$ and $\mathrm{C} 2$. In practice, the industries work with a useful column volume, which means that the rupture and saturation time can be decided according to need or the output concentration can be equivalent to a reference value established by current legislation (Karunarathne and Amarasinghe, 2013). The performance of RHA activated at different bed heights was analyzed in the Statistica ${ }^{\circledR}$ program, Version 7.0. The parameters were adsorption capacity for the rupture and saturation times for the analysis of chemical oxygen demand; real and apparent color were performed with a completely randomized design and the results were treated by Analysis of Variance (ANOVA) and, when significant, the Fischer test was performed $(\mathrm{p}<0.05)$.

\section{RESULTS AND DISCUSSION}

The results were obtained by the curves considering the height of the bed of $5 \mathrm{~cm}(\mathrm{C} 1)$ and $20 \mathrm{~cm}(\mathrm{C} 2)$ and initial organic matter concentration of $4538.61 \pm 190.82 \mathrm{mg} . \mathrm{L}^{-1} \mathrm{COD}, \mathrm{pH} 8.14$ , apparent color of $176000 \pm 1885.62 \mathrm{UC}$ and true color of $16600 \pm 942.81 \mathrm{UC}$ (Figures 3 and 4). The parameters $t_{r}$ and $t_{s}$ were calculated (Table 1), along with the adsorption capacity, residual concentration of COD and color. The $t_{r}$ refers to the time of rupture or time required for the adsorbate to be detected at the exit of the bed and $t_{s}$ refers to the time required for bed exhaustion.

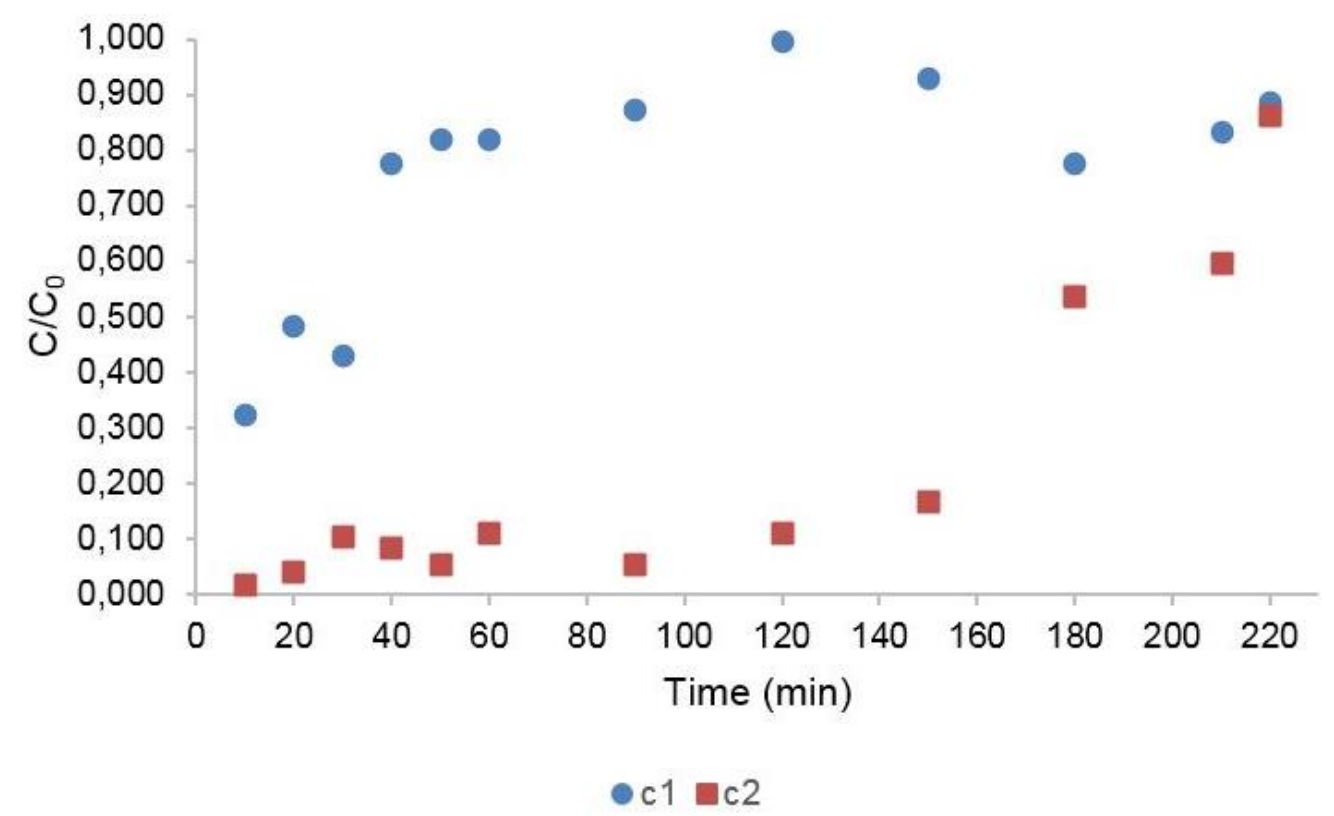

Figure 3. Rupture curves for $\mathrm{C} 1$ (bed height of $5 \mathrm{~cm}$ ) and $\mathrm{C} 2$ (bed height of $20 \mathrm{~cm}$ ) treatments for the removal of organic matter (COD). 


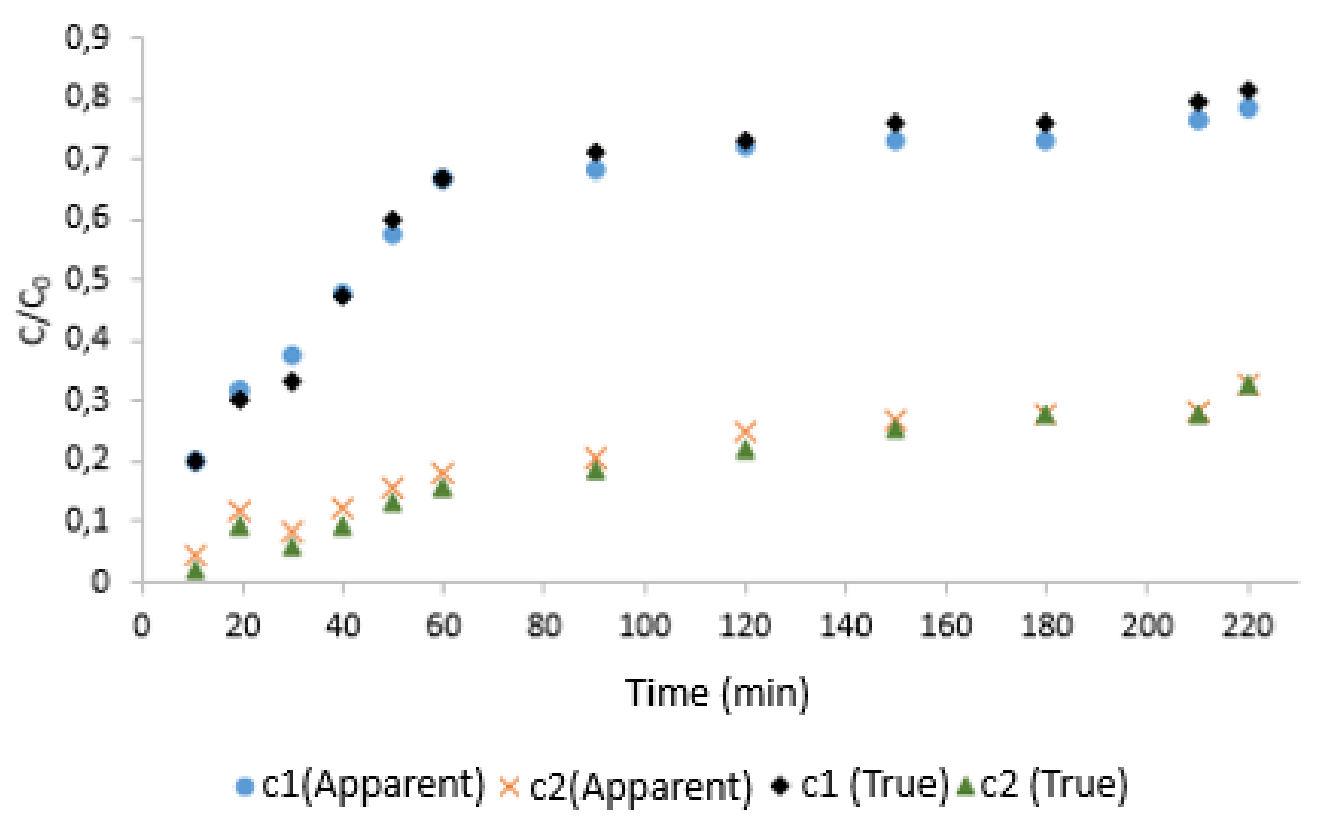

Figure 4. Rupture curves of apparent color and true color removal for $\mathrm{C} 1$ and $\mathrm{C} 2$.

Table 1. * Characteristics of the $\mathrm{C} 1$ and $\mathrm{C} 2$ tests for COD and apparent color removal.

\begin{tabular}{|c|c|c|c|c|c|c|}
\hline \multirow{2}{*}{ Parameters } & \multicolumn{2}{|c|}{ COD } & \multicolumn{2}{|c|}{ Apparent color } & \multicolumn{2}{|c|}{ True color } \\
\hline & $\mathrm{C} 1$ & $\mathrm{C} 2$ & $\mathrm{C} 1$ & $\mathrm{C} 2$ & $\mathrm{C} 1$ & $\mathrm{C} 2$ \\
\hline Bed Height $(\mathrm{cm})$ & 5 & 20 & 5 & 20 & 5 & 20 \\
\hline Flow $\left(\mathrm{mL} \min ^{-1}\right)$ & 8 & 8 & 8 & 8 & 8 & 8 \\
\hline $\mathrm{t}_{\mathrm{r}}(\min )$ & 10 & 120 & 20 & 40 & 30 & 50 \\
\hline $\mathrm{q}_{\mathrm{r}}\left(\mathrm{mg} \mathrm{g}^{-1}\right)$ & $10,23^{\mathrm{a}}$ & $40,77^{\mathrm{ab}}$ & $79,77^{\text {acd }}$ & $54,81^{\mathrm{bc}}$ & $110,5^{\mathrm{d}}$ & $60,56^{\mathrm{bc}}$ \\
\hline **Parameters residual $\mathrm{l}_{\mathrm{r}}$ & 1467,89 & 503,145 & 5633,3 & 2216,67 & 5550 & 2216,7 \\
\hline $\mathrm{t}_{\mathrm{s}}(\min )$ & 40 & 220 & 210 & $220 * * *$ & 210 & $220 * * *$ \\
\hline $\mathrm{q}_{\mathrm{s}}\left(\mathrm{mg} \mathrm{g}^{-1}\right)$ & $13,55^{\mathrm{a}}$ & $11,57^{\mathrm{a}}$ & $289,33^{\mathrm{g}}$ & $220,15^{\mathrm{e} f * * *}$ & $242,67^{\mathrm{cf}}$ & $207,80^{\text {e**** }}$ \\
\hline$* *$ Parameters residual ${ }_{\mathrm{s}}$ & 3522,013 & 3914,37 & 13466,67 & $5716,67 * * *$ & 13133,33 & $5383,33 * * *$ \\
\hline
\end{tabular}

*Means followed by the same letter are not significantly different at the $95 \%$ confidence level (Fischer's test). **Parametres residual: Cod (mg. $\left.\mathrm{g}^{-1}\right)$; Color (UC). ***values obtained for the total operating time.

Figures 3 and 4 show that the increase in height of bed positively affected the efficiency of removal of organic load and leachate color, since the career time of the rupture of the $\mathrm{C} 2$ treatment was greater than that of the $\mathrm{C} 1$ (Table 1). The $\mathrm{C} 2$ treatment had shown a removal efficiency up to $86.64 \%$ of the true color, and $87.4 \%$ of the apparent color and $88.91 \%$ of the COD. On the other hand, the treatment $\mathrm{C} 1$ showed a efficiency for removal of $66.56 \%$ of the true color, $67.65 \%$ of the COD and $67.99 \%$ of the apparent color. These values are compatible with other study developed by Kawahigashi et al. (2014), in which authors verified the effectiveness of adsorption with commercial granular carbon of coconut endocarp as post treatment of landfill leachate, removing around 45 to $76 \%$ of COD, 95 to $100 \%$ of apparent color and 94 to 100 of the true color under conditions of $\mathrm{pH}=4.0, \mathrm{Fe}^{3+}$ dose $\left(\mathrm{mg} \mathrm{Fe}^{3+} . \mathrm{L}^{-1}\right)$, initial COD of $303 \mathrm{mg} . \mathrm{L}^{-1}$ and height of bed of $9 \mathrm{~cm}$.

Vieira (2014), in a similar study, found that with the increase of the height of the bed from $10 \mathrm{~cm}$ to $30 \mathrm{~cm}$, an improvement in performance was shown, increasing the rupture time and the percentage of removal at this condition. The best condition found in this study was $30 \mathrm{~cm}$ of the bed height, yellow tartrazine dye concentration of $50 \mathrm{mg} \mathrm{L}^{-1}$, rupture time of $88 \mathrm{~min}$, 
maximum column capacity of $108.0 \mathrm{mg} \mathrm{g}^{-1}$ and the removal percentage of $85.9 \%$, using the chitosan as adsorbent.

The behavior shown in our study corroborates with that found by Vieira (2014), with the variation of the bed height a factor with a great influence in the phenomenon of adsorption. In addition, the height of the bed, particle size, pore size, molecular weight and pollutant concentration are other parameters that altered the characteristics of the adsorption process.

Regarding the particle size, generally, materials with lower granulometry have a higher capacity for pollutant removal, i.e., adsorbent with particle size $0.297-0.841 \mathrm{~mm}$ results in 2 to 3 times greater capacity for removal than adsorbents with a particle size of $0.420^{-1} .680 \mathrm{~mm}$ (Tauma, 2013). Thus, it can be affirmed that the particle size of the activated charcoal of rice husk ash showed a great capacity of removal influence on the organic matter and color of the landfill leachate.

Methylene blue index is a technique used to indirectly measure the pore size of the adsorbents; the materials with high methylene blue index indicate that the material analyzed is mesoporous ( 2 to $50 \mathrm{~nm}$ ) (Kawahigashi et al., 2014). In this perspective, the activated carbon of RHA presents elusive indication of material with mesopores, according to the value of index of methylene blue found of $10.05 \mathrm{mg} \cdot \mathrm{g}^{-1}$. The presence of pores of the coal used in the study can be observed in the SEM image presented in Figure 2.

According to Castilhos Junior et al. (2010), one of the main constituents of the recalcitrant organic matter of the leachate are the humic substances and fulvic acids that are high molecular weight substances. These substances are responsible for the coloration of leachates (Queiroz et al., 2011). Thus, the high efficiency of the systems can be attributed to the large molecular weight of humic substances and fulvic acids that can easily be removed from the aqueous solution by adsorption through two effects: solubility and surface attraction. Also, the principle of destabilization due to particle collisions can be highlighted. This phenomenon occurs due to the high concentration of the contaminant in solution (Tauma, 2013), as shown in the characterization of the leachate with high staining, expressed as apparent and true color.

\section{CONCLUSION}

In summary, the study was satisfactory for the dynamic process of adsorption in a fixed bed. The study showed that the use of activated rice husk ash is a promising method for posttreatment of stabilized landfill leachate with regard to COD removal, apparent and true color. The experiment showed removal efficiency higher than $60 \%$ for the analyzed parameters.

The $20 \mathrm{~cm}$ of height of bed was the system that provided better performance and longer operation time in the leachate treatment. Further studies changing other parameters are highly recommended.

\section{ACKNOWLEDGEMENTS}

This study was financed in part by the Coordenação de Aperfeiçoamento de Pessoal de Nível Superior - Brasil (CAPES) - Finance Code 001, and Brazilian National Council for Scientific and Technological Development (CNPq) and Research Support Foundation of the State of Rio Grande do Sul (FAPERGS).

\section{REFERENCES}

ANJU, S.; KANI, K. M. Assessing the Effectiveness of Rice Husk Ash in Treating Municipal Leachate. International Journal of Emerging Technology and Advanced Engineering, v. 7, p. 42-54, 2017. 
APHA; AWWA; WEF. Standard Methods for the Examination of Water and Wastewater. 21. ed. Washington, 2005.

ANDRADE, R. M. de; FERREIRA, J. A. A gestão de resíduos sólidos urbanos no brasil frente às questões da globalização. Revista Eletrônica do Prodema, v. 6, n. 1, p. 7-22, 2011.

CASTILHOS JUNIOR, A. B.; DALSASSO, R. L.; ROHERS, F. Pré-tratamento de lixiviados de aterros sanitários por filtração direta ascendente e coluna de carvão ativado. Engenharia Sanitária e Ambiental, v. 15, n. 4, p. 385-392, 2010.

HOSSEINI, H. M. S.; KARIMI. R; NOVAIR. S. B.; TABATAHAEI. S. H. A study of treated municipal waste leachate and Zeolite effects on soils. Iran Agricultural Research, v. 34, n. 2, p. 109-116, 2015. http://dx.doi.org/10.22099/iar.2016.3533

KARUNARATHNE, H. D. S. S.; AMARASINGHE, B. M. W. P. K. Fixed Bed Adsorption Column Studies for the Removal of Aqueous Phenol from Activated Carbon Prepared from Sugarcane Bagasse. Energy Procedia, v. 34, p. 83-90, 2013. https://dx.doi.org/10.1016/j.egypro.2013.06.736

KASMAN, M.; IBRAHIM, S. The Removal of Iron from Landfill Leachate by Rice Husk Packed Bed Column. Journal of Chemical and Pharmaceutical Research, v. 8, n. 8, p. 1255-1262, 2016.

KAWAHIGASHI, F.; MENDES, M. B.; ASSUNÇÃO JÚNIOR, V. G. DA; GOES, V. H.; FERNANDES, F.; HIROOKA, E. Y.; KURODA, E. K. Pós-tratamento de lixiviado de aterro sanitário com carvão ativado. Engenharia Sanitária e Ambiental, v. 19, n. 3, p. 235-244, 2014. https://dx.doi.org/10.1590/S1413-41522014019000000652

LE VAN, K.; LUONG THI, T. T. Activated carbon derived from rice husk by $\mathrm{NaOH}$ activation and its application in supercapacitor. Progress in Natural Science: Materials International, v. 24, n. 3, p. 191-198, 2014. https://doi.org/10.1016/j.pnsc.2014.05.012

MOJIRI, A.; AZIZ, H. A.; ZAMANA, N. Q.; AZIZ, S. Q.; ZAHED, M. A. Powdered ZELIAC augmented sequencing batch reactors (SBR) process for co-treatment of landfill leachate and domestic wastewater. Journal of Environmental Management, v. 139, p. 1-14, 2014. https://doi.org/10.1016/j.jenvman.2014.02.017

MUNIANDY, L.; ADAM, F.; MOHAMED, A. R.; NG, E-P. The synthesis and characterization of high purity mixed microporous/mesoporous activated carbon from rice husk using chemical activation with $\mathrm{NaOH}$ and $\mathrm{KOH}$. Microporous and Mesoporous Materials, n. 197, p. 316-326, 2014. https://doi.org/10.1016/j.micromeso.2014.06.020

QUEIROZ, L. M.; AMARAL, M. S.; MORITA, D. M.; YABROUDI, S. C.; SOBRINHO, P. A. Aplicação de processos físico-químicos como alternativa de pré e pós-tratamento de lixiviados de aterros sanitários. Engenharia Sanitária e Ambiental, v. 16, n. 4, p. $403-$ 410, 2011.

TAUMA, S. L. Testes acelerados em colunas de pequena escala: o uso de carvão ativado granular em projetos de reúso de efluentes de refinarias de petróleo. 2013. 227f. Dissertação (Mestrado em Ciências) - Universidade Federal do Rio de Janeiro, Rio de Janeiro, 2013.

VIEIRA, M. G. Quitosana imobilizada em suporte inerte para a adsorção de corantes alimentícios em coluna de leito fixo. 2014. 91 f. Dissertação (Mestre em Engenharia e Ciência de Alimentos) - Universidade Federal do Rio Grande, Rio Grande, 2014. 